DOI: https://doi.org/10.36910/6775-2524-0560-2021-43-09

УДК 004.77; 004.3

Inessa Kulakovska, $\mathrm{PhD}$ of Physical and Mathematical Sciences

https://orcid.org/0000-0002-8432-1850

Andriy Satura, Master of Computer Science

http://orcid.org/0000-0002-7433-8464

Department of Intelligent Information Systems, Petro Mohyla Black Sea National University.

\title{
DESIGN OF A SUBSYSTEM FOR PLANNING AND OPTIMIZING THE BEHAVIOR OF STAND-ALONE DEVICES FOR SMART HOMES BASED ON DATA ANALYSIS
}

Inessa Kulakovska, Andriy Satura. Design of a subsystem for planning and optimizing the behavior of stand-alone devices for smart homes based on data analysis. The article describes purposes of Smart Home systems with some of their advantages and disadvantages. Found implementation trends of such systems in modern life, substantiated development relevance. Described general structure of Smart Home system, investigated modern approaches to implementation of Smart Home control systems. The article is dedicated to designing of Smart Home model. The authors analyzed literature about Internet of Things and identified basic requirements for the test model: connectivity, control, data analysis. Considered two of the key components: data base and system node. The authors singled out the main subsystems of the model: interfaces, sensors, heating control, water boiling control, device activity events monitoring and analyzing the date based on time series. The software implementation requires the use of modern lightweight technologies combined with secure data transfer and ease in use user interfaces.

Keywords: Smart home, Smart Technologies, Internet of Things, technology of management.

Інесса Кулаковська, Андрій Сатура. Проектування підсистеми для планування та оптимізації поведінки автономних пристроїв для розумних будинків на основі аналізу даних. У статті описано проектування систем розумного будинку з їх перевагами та недоліками. Оглянуто тенденції впровадження таких систем у сучасному житті, обгрунтовано актуальність розвитку. Описано загальну структуру системи Smart Home, досліджено сучасні підходи до впровадження систем управління Smart Home. Стаття присвячена проектуванню підсистеми моделі розумного будинку. Автори проаналізували літературу про Інтернет речей та визначили основні вимоги до тестової моделі: підключення, контроль, аналіз даних. Розглянуто два ключові компоненти: базу даних та системний вузол. Автори виділили основні підсистеми моделі: інтерфейси, датчики, контроль нагріву, контроль кипіння води, моніторинг подій активності пристрою та аналіз дати на основі часових рядів. Впровадження програмного забезпечення вимагає використання сучасних легких технологій у поєднанні з безпечною передачею даних та простотою користування користувальницькими інтерфейсами.

Ключові слова: розумний дім, розумні технології, інтернет речей, технологія управління.

Инесса Кулаковская, Андрей Сатура Проектирование подсистемы планирования и оптимизации поведения автономных устройств для умных домов на основе анализа данных. В статье описывается проектирование систем Умного дома с указанием их достоинств и недостатков. Рассмотрены направления внедрения таких систем в современную жизнь, обоснована актуальность разработки. Описана общая структура системы Умного дома, исследованы современные подходы к реализации систем управления Умным домом. Статья посвящена проектированию подсистемы модели Умного дома. Авторы проанализировали литературу об Интернете вещей и определили основные требования к тестовой модели: возможность подключения, контроль, анализ данных. Рассмотрены два ключевых компонента: база данных и системный узел. Авторы выделили основные подсистемы модели: интерфейсы, датчики, контроль нагрева, контроль кипения воды, мониторинг событий активности устройств и анализ даты на основе временных рядов. Программная реализация требует использования современных облегченных технологий в сочетании с безопасной передачей данных и простыми в использовании пользовательскими интерфейсами.

Ключевые слова: умный дом, умные технологии, интернет вещей, технологии управления.

\section{Introduction}

Throughout history, our homes have evolved with us. The peculiarity of the modern stage is the appearance of a large number of service equipment, the active introduction of innovative changes for humans, as digital technologies have changed the world around us, the Internet has destroyed the spatial boundaries for the dissemination of information. All this led to the inevitability of the concept of a smart home. Smart Home is usually described as living building where comfort, everyday activities, security and energy saving is controlled or supervised by smart devices and special software that are connected into the local shared network. It is considered that the very first definition to Smart Home was first formulated at the Washington Institute of Intelligent House and looks as follows: "smart home" is a building that provides productive and efficient use of workspace [1]. We can partially agree with this definition, bearing in mind that the functions and criteria of a "smart home" are constantly being reviewed and clarified.

Introducing more and more facilities using "smart home" systems, the community of manufacturers and integrators of these systems has clarified the concept of intelligent building. The basis of the concept is the principle of the most efficient use of space and its basic elements: structure, systems, services and 
management. This principle has become common to commercial and residential real estate, given the difference in the purpose of the objects [2].

\section{Smart Home functionality}

Modern systems based on wireless networks made it easier to install, configure and control Smart Home functionality, augment it with a wide variety of smart devices. Nowadays there are different types of systems for Smart Home control that provide ease of use. There are two types of Smart Home control: remote and local. The remote-control interfaces allow users to manage their smart devices and Smart Home systems from almost any location in the world via the Internet. At the same time, local-control interfaces mostly presented by single control unit installed somewhere in the building proving access to all the features from the one place (it could be software installed on personal computer or wall panel).

The scenarios developed during the research will not only provide a way to solve some problems, but also show the ways of future development of the system and its application on real examples. This will definitely make it easier for the user to work with such a system in the first steps, and the system will become more flexible and even smarter.

Nowadays, the question of training of the Smart Home systems is more relevant than ever. In the context of research, they can be filled by implementing STEM-projects, using Smart-technologies, exploring the possibilities of the Internet of Things [3].

Smart Home technology embodies all the above concepts. A "smart home" can be understood as a system that provides security and conservation of resources (including comfort) for all users. In case of an advanced system, it can be able to recognize and respond to specific situations that occur at home: one of the systems can control the behavior of others using pre-built algorithms. In addition, several subsystems are automated, which provide a synergistic effect for the whole complex [4].

Currently, there are companies that are actively implementing systems such as "smart home", which are able to self-learn, using data on the habits of the owner in everyday life, taking into account various factors. Typically, neural networks and regression models are used to construct patterns of behavior and further process them. Some systems allow you to set certain rules and restrictions, which increases the reliability and stability of their work.

Let us give base characteristics to modern Smart Home functions, such as energy efficiency, security, climate control, entertainment.

\section{Basic principles}

Advanced automated Smart Home systems let us use modern technologies to implement effective and reliable utilities for energy conservation. By integrating informational and communicational technologies in systems with renewable energy sources (like solar and wind power) Smart Homes can autonomously make decisions about conservation and usage of the energy which can decrease negative anthropogenic factors on the environment, effectively distribute energy between devices [4]. To do so it is required to use such systems that incorporate numerous sensors that react on external and internal factors and events, including household activities. Obviously, such systems must be based on appropriate software which also has to be designed and implemented correctly to meet the main requirements of efficiency and productivity.

Implementing of the efficient and high-performant system can prove relatively simple using technologies like .NET 5 which provides variety of power tools. The main advantage of using such a technology is in that all of the features are compatible while keeping lots of different stacks and directions covered: for Web API we can use ASP .NET, for training intelligent systems it is Microsoft ML, for mobile applications - Xamarin Forms etc. Also, it enables using different languages for implementing features you require. For instance, $\mathrm{F} \#$ language is great at data analysis and prototyping while $\mathrm{C \#}$ is useful in places where we do need high-performance or implementing code for client/server applications.

There is also great tooling provided by Microsoft Azure for IoT which provides the industry's widest portfolio of services and capabilities to help you perform tasks on the periphery and in the cloud, tailored to your needs and industry requirements. Implementing micro-services and applications for micro-devices is also available.

Given that, one should consider using these tools for implementing Smart Home systems for maximum efficiency. If there is any need for extra optimizations for applications written for microcomputers, it is possible to program such devices using $\mathrm{C}++$ language but still keeping connections between single components intact which is possible to implement using language-agnostic data transfer and signaling protocols.

\section{Subsystem for planning}

Smart Home system is built of individual components that should be replaceable and somewhat autonomous. Given that, it can be logically separated in subsystems and device groups. The system 
components can be either logical or physical. The best way to connect them is to do so using low coupling principle which gives us possibility to replace any single element with another or to add new ones without making global changes.

Creating system with low coupling is possible due to implementing services and entities with the corresponding software and design techniques combined with abstracting from details. Such an approach could result in decreased overall performance of the system, especially when it is built over weak and badly optimized hardware or operating systems. But modern devices are capable of executing more instructions in combination with lower power consumption comparatively to previous device series hence it should not be a big deal.

Achieving high performance and better energy consumption efficiency of the Smart Home system itself is possible in case of using hardware and software provided by the same company or with full compatibility if different manufactures involved. It is known as so-called ecosystem, where protocols and components-wise compatibility takes place. Obviously, the software/hardware ecosystem has its pros and cons. As pros we can give as example high-quality and responsibility of the technical support team of the provider company, reliable and well-known brand name reinforced with years of experience on market. As about cons, it is sometimes about pricing, license terms, availability on the local market, restricted system extension and control over data or system itself.

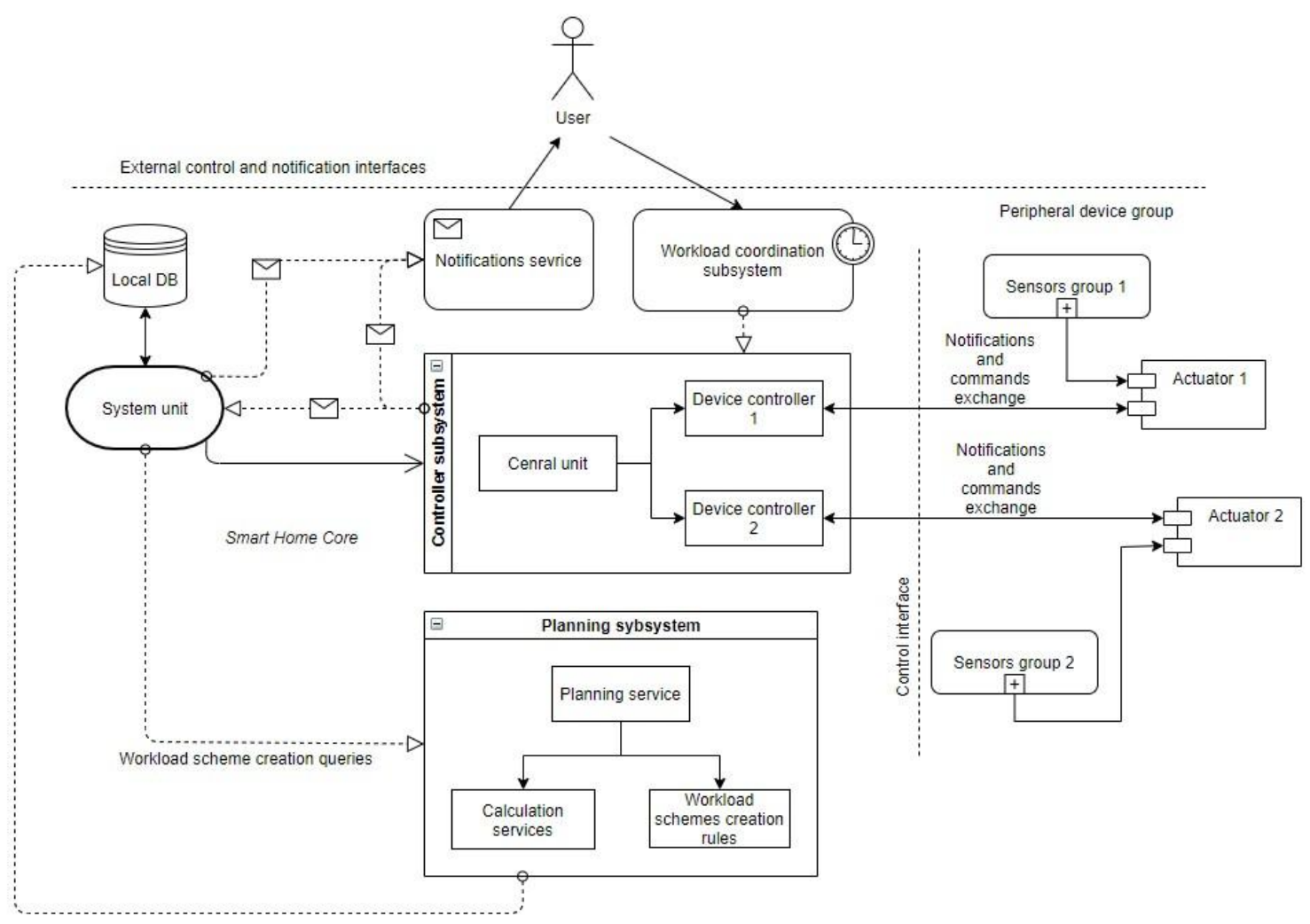

Figure 1. Hierarchical components structure scheme

If it is possible to extend the Smart Home system with additional components, one should consider integrating subsystems that analyze and manage devices' routines in specific manner. Such a subsystem can improve operation of the entire system by searching for dependencies and correlations between device activity, power consumption and specific productivity over time. Based on data analysis it could create and operate on basic behavior patterns for each one device or device group, which is useful in control subsystems configuration.

It is important to pay attention to the need for devices' routines coordination to provide optimal workload distribution in local power grid. Besides, considering activity increasing and decreasing periods during the day is also an important task for implementation. Having the information about such a time ranges it is possible to appoint execution of specific actions at specific time to make the whole system use resources in more effective way without other interrupting other processes. Such a 
task can be assigned to subsystem for planning and optimizing of devices operations in Smart Homes. The picture below shows the approximate structure of the Smart Home system extended with auxiliary subsystems and components. The system (Figure 1) has to be modular to make it possible to achieve the main goals. It is mandatory to make a decomposition of the whole system, breaking it down to separate autonomous blocks and adjust their interconnections step by step according to principles of clean architecture. This will make the system flexible and easily extensible, which in the long run provides an opportunity to augment it with new components or easily replace existing ones. Of course, a properly designed system will be faulttolerant and protected from the threat of any criminal activity.

Hierarchically the system can be described as such:

1) External control and notifications interfaces.

- Mobile devices (smartphones, tablets etc.).

- Control panels.

2) System core.

- Workload coordination subsystem.

- Notification service.

- Control subsystem.

i. Central unit.

ii. Virtual device controllers' group.

- Planning subsystem.

i. Planning service.

ii. Calculation and analysis services.

iii. Working schemes creation rules.

- System unit.

- Database.

3) Device control and monitoring interfaces.

4) Peripheral devices group.

- Actuators.

- Sensors.

The given structure is an example of what it might be in the real-world application and can be different from the actual implementation, including possible modifications for specific users according to their needs and possibilities. In this article we will cover only those components that are connected to subsystem for planning.

\section{Application of the planning subsystem}

Devices can be controlled and monitored using other devices such as control panels and smartphones. The first type of device is directly connected to the local network in which the system operates and allows you to directly control processes without any warries about external intervention. Smartphones should only be used to obtain basic information and possibly requests from the system that require prompt intervention by the owner.

The main task for the implementation of external interfaces for monitoring and management should be the security of private information. In particular, this can be achieved by severely limiting possible actions. The control panel will allow you to fully control the system, while inside the house in a secure place, blocked by password or biometrics (fingerprint scanner, face recognition, etc.), and without access to the WAN, which will protect it from outside burglary. At the same time, the control/notification interface for mobile devices should be as limited as possible and with several levels of protection, such as encryption and strong passwords, as there are many tools for hacking smartphones, as well as breaking into the communication channel. A separate system module must provide a secure external communication interface via the mobile phone, which in turn will check the traffic of incoming and outgoing information in order to block potentially dangerous signals or information leakage. Through these interfaces, the planning subsystem is able to notify the owner of various changes, provide reports on the work performed and provide basic statistical information.

Before moving on to the planning subsystem, we first briefly consider two key components: the database (DB) and the system node. The database obviously performs the task of storing information about various events in the system, collected information about devices and their activities, modes of operation and more. Such a database should be dedicated and secure, provide information or receive it only through secure interfaces. System node is the root of the layout, i.e., it acts as a basic component, through which the rest of 
the system kernel is initialized, control and message interfaces are transmitted to child services, the validity of operations is checked, registration and fault processing, etc.

The planning subsystem itself consists of several groups of independent components that communicate through certain communication interfaces. Calculation services include data analysis tools: noise and anomaly signal elimination, clustering and classification, evaluation of collected data models. Services of construction and optimization of operating modes and behavior of devices. Such services are represented by separate software units that connect to the subsystem for each type of device. For example, a library/software module/script package specializing in devices such as temperature sensors, electric heaters, etc. may be created for a heating system. Such a module is able to effectively adjust the routine of the heating system, taking into account their key features. In fact, the idea of designing and supplementing the planning subsystem with specialized modules for each type of device provides the extensibility and efficiency of such a system. The scheduling service itself is a root component of this subsystem and acts as an aggregator of data and processes, a container/controller of functional blocks. It is through its interfaces that the entire system is able to obtain the necessary information to regulate the routines of devices.

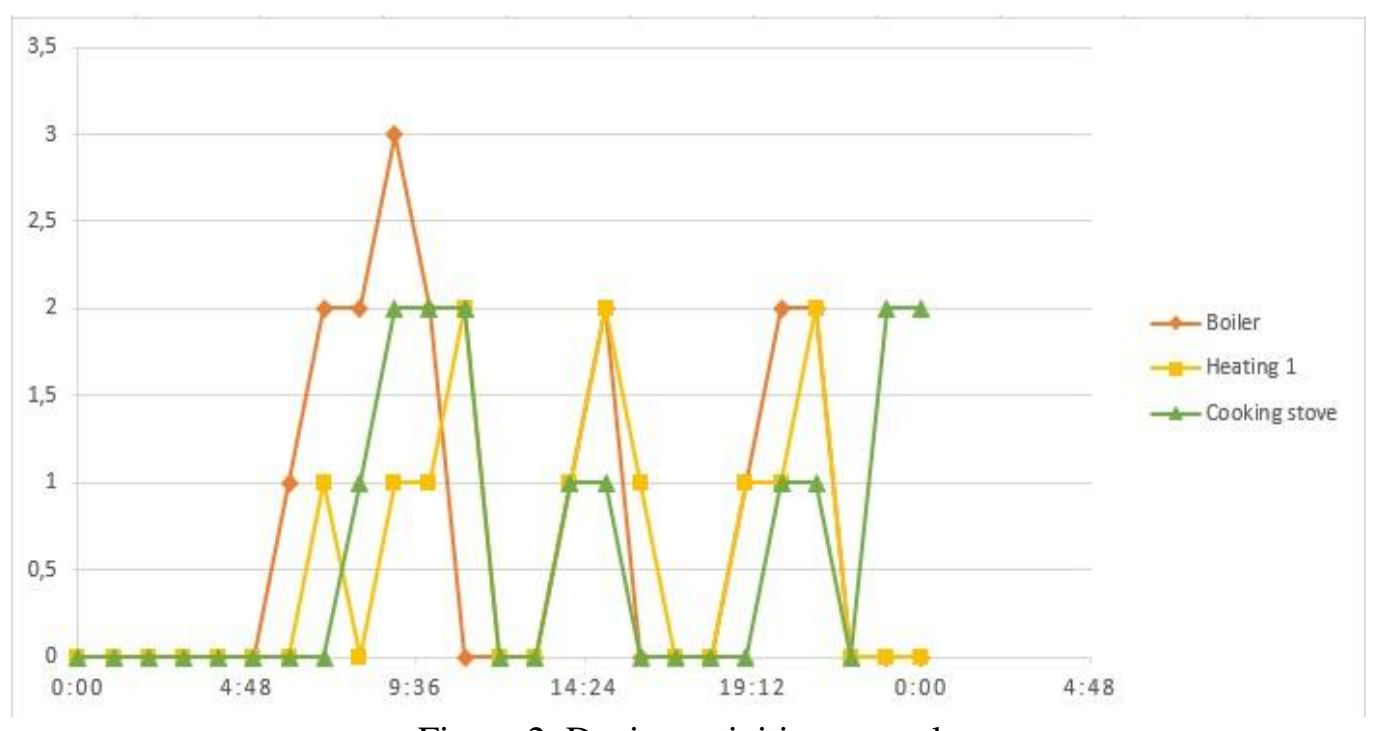

Figure 2. Device activities example

The principle of operation of the system (based on the planning subsystem) is as follows: based on the collected information about the activity of devices, external factors (such as weather conditions), external time information (working days, weekends, holidays, etc.) it forms a basic model of behavior, relationships various factors, etc.; the system assumes the role of coordinator of devices; user activity is constantly analyzed in order to improve the formation of device operating routines, identify patterns of behavior and more.

We can see an example (Figure 2) of collected data through the time on the picture below. Each device sends signals to the controllers, from there the signals are propagated to the system core. At that point, each signal is stored to the log (in data base) and also being provided to the planning subsystem if it is training stage running. Then, each signal is operated by the planning system, data analysis tools and so on. It is visually recognized that some devices has correlations in their activity thought the time of the day.

\section{System working stages and data analysis}

We can distinguish the following basic stages of the system.

Training. Approximately one calendar week, starting from the first day (Sunday or Monday, depending on the region) including weekends;

Configuring. Performed at the end of each working day during training, as well as at the end of the week, month, quarter during normal work. At this time, the analysis of the collected statistical information is performed, the operating modes are adjusted, the logs of events and failures are checked. After the completion of the first stage it is performed only in the hours of least activity in the house to avoid conflicts between data flows;

Normal operation. The basic minimum of information exchange is performed, data about device activity and indicators from external sensors are collected, the log of failures is kept. In this mode, the system tries to perform least interactions between components to save energy, especially during periods of activity. 
The mathematical formulation of the problem of studying individual factors and their relationships on the collected data is known as the problem of data analysis. This task includes the processes of studying, filtering out, transforming and modeling data in order to extract useful information, draw conclusions and to support decision-making. Data analysis includes many variations and approaches, covering a variety of techniques and used in business, science and the social sciences. Properly processed and analyzed data allow you to make a clear reflection of various phenomena and processes that can be used in the future in the formation of certain decisions, forecasts and more.

Data analysis includes utilities for filtering out redundant information, normalization of data, its transformation. In particular, a useful technique for processing statistical information is Dynamic Time Warping (DTW), which finds the optimal alignment between two time series [5]. DTW is used as a metric to establish the similarity of two data streams in the time space.

As for the data analysis for a Smart Home this technique can be useful because we are dealing with consistent data - events and states of devices that occur over time. Standard clustering methods are not able to work effectively with the data presented in time series (Figure 3). You must first convert such data, after which you can perform the necessary actions, including the actual clustering.

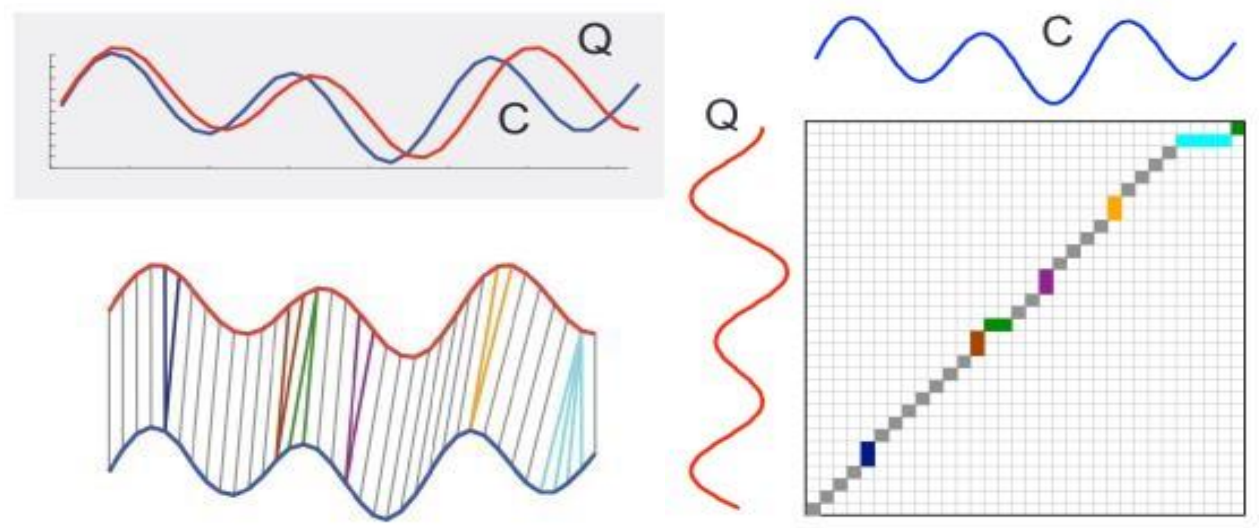

Figure 3. (a) Time series $\mathrm{C}$ and $\mathrm{Q}$ and the linked points in time by DTW.

(b) Minimum warping path $\mathrm{W}$ through the LCM of time series C and Q.

The figure above depicts that it is quite difficult to perform any data analysis on the initial representation of time series. Certain patterns and connections of events in individual series can be traced only visually, but with a noticeable shift. Whereas when comparing due to time warping, it is possible to trace areas where changes or similarities are clearly visible.

This method should be used when working with data in the time space. Because it will be exceedingly difficult for a computer program to process time data.

It is also planned to use software to generate source code that will be targeted to each individual unit of the system, thus achieving both high performance of components and their energy efficiency. After all, the use of software that is designed to execute certain instructions specific to a particular device, avoids unnecessary abstractions and CPU time. And this is a very important factor for microdevices, which are usually designed to consume little energy and are not able to perform complex operations in a short period of time.

\section{Conclusions}

With the increasing computing power of gadgets, many smart home technologies and the Internet of Things are becoming more manageable. The basic rules and recommendations for building a complex product at the level of systems and subsystems also applies for Smart Home systems, so the system as a whole and individual components were identified.

At the moment, there are not many solutions that would integrate all the details of "smart home" systems. That is, most projects focus on certain aspects of these systems. Namely, stand-alone devices that are not connected to the central control system, or large networks that include individual houses, mostly performing tasks for collecting large amounts of information and their further analysis. And often, consumers are limited to the use of devices from one company, part of a single, but closed, ecosystem or individual devices that interact poorly with each other.

The article describes the approach to design and implementation of a Smart Home management system and developed the principle of operation of the system (based on the planning subsystem), which is as follows: based on collected information about device activity, external factors (weather conditions), additional time 
information (days, weekends, holidays, etc.) constructing basic model of behavior, the relationship of various factors, etc.; the system assumes the role of coordinator of devices; user activity is constantly analyzed in order to improve the formation of device operating routines, identify patterns of behavior and more.

The results of the implementation can be used to create reliable and energy-efficient automated systems that are able to independently shape their own behavior, adapting to each user, which will make life easier and save time.

\section{References}

1. Model of Professional Retraining of Teachers Based on the Development of STEM Competencies. / N.Balyk, O. Barna, G. Shmyger, V. Oleksiuk. // CEUR Workshop Proceedings. - 2018. - P. 318-331.

2. Understanding user perceptions of privacy, and configuration challenges in home automation / K.Kaaz, A. Hoffer, M. Saeidi, A. Sarma. // Symposium on Visual Languages and Human-Centric Computing. - 2017. - P. 297-301.

3. Principles of smart home control. Lecture Notes in Computer Science / S.Davidoff, M. K. Lee, C. Yiu, J. Zimmerman. - 2016.

4. Oteafy, S.M.A., Hassanein, H.S.: Resource Re-use in Wireless Sensor Networks: Realizing a Synergetic Internet of Things. Journal of Communications 7(7), 484-493 (2012). doi:10.4304/jcm.7.7.484-493

5. Ameena Saad al-sumaiti. Smart Home Activities: A Literature Review / Ameena Saad al-sumaiti, Mohammed Hassan Ahmed, Magdy M. A. Salama. // Electric Power Components and Systems. - 2014. - P. 294-305.

6. Pjotr Roelofsen. Time series clustering / P. Roelofsen. // Vrije Universiteit Amsterdam, Faculty of Science. - 2018. 